\title{
Organic-matter vitrinite reflectance variability in the Outer Carpathians, Poland: relationship to tectonic evolution
}

\author{
Magdalena ZIELIŃSKA ${ }^{1, *}$ \\ 1 University of Silesia, Faculty of Earth Sciences, Będzińska 60, 41-200 Sosnowiec, Poland
}

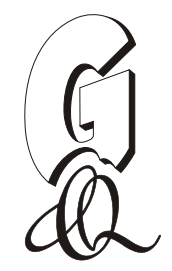

Zielińska, M., 2017. Organic-matter vitrinite reflectance variability in the Outer Carpathians, Poland: relationship to tectonic evolution. Geological Quarterly, 61 (1): 214-226, doi: 10.7306/gq.1338

\begin{abstract}
Random vitrinite reflectance of allochthonous plant material varies throughout all the flysch sedimentary units of the Outer Western Carpathians. The vitrinite reflectance of coalified phytogenic matter is variable even within the same lithostratigraphic unit. There is no clear relationship between random vitrinite reflectance and stratigraphy (age of particular strata) within surface samples. The typical pattern of increasing random reflectance with depth in boreholes is unsettled by $R_{r}^{0}$ "jumps" which occur within folds and overthrusts. However, this study revealed a trend of increasing random vitrinite reflectance from north to south in the area of the Magura Unit. A compressional regime involving phases of uplift and burial, varying from place to place in the flysch basin, was the main factor influencing coalification. The initial maturity of organic matter transported to the marine environment was a secondary factor. A degree of coalification had occurred in the flysch sediments prior to the main stage of fold-and-thrust movements associated with the phase of maximum tectonic subsidence at the end of the Eocene. It is generally assumed that coalified plant material dispersed in sedimentary rocks experienced the same physical and chemical changes as those in larger accumulations of coal. Coalification of phytogenic material coeval with flysch in the Outer Carpathians corresponds to the interval from sub-bituminous to low-medium-rank bituminous coal.
\end{abstract}

Key words: Outer Carpathians, organic matter, thermal maturity, vitrinite reflectance.

\section{INTRODUCTION}

The focus of current research on organic matter in the Carpathians is the assessment of its thermal maturity to identify areas prospective for hydrocarbons. Most of this research is centred in the eastern part of the Polish Outer Carpathians and on those flysch sequences that exhibit the highest contents of organic matter and have a high potential for hydrocarbon generation (Kuśmierek et al., 1995; Kotarba and Nagao, 2008; Więcław et al., 2012). Geochemical analyses allowing to estimate the amounts of organic carbon, types of organic material and their maturity in the flysch formations have been determined by, e.g. Kuśmierek (1990), Curtis et al. (2004), Lewan et al. (2006), Wójcik-Tabol (2006, 2015), Kotarba et al. (2007), Kosakowski et al. (2009) and Semyrka (2009). Menilite shales (e.g., Hempel, 1955; Kosakowski, 2013), long deemed to be of great importance in determining stem areas for hydrocarbon deposits, are the key interest.

Coalified organic matter mainly of plant origin and exhibiting diverse morphological forms is common in certain parts of flysch sequences. Its degree of coalification ranges from sub-bituminous $C$ to high-volatile $B$ bituminous coal (e.g., Wag-

\section{*E-mail: magdalena.zielinska@us.edu.pl}

Received: April 12, 2016; accepted: July 5, 2016; first published online: December 29, 2016 ner, 1980, 1992, 2011). Examination, in the context of geological structure, of the degree of coalification and of morphological forms that characterize the coalified organic matter may significantly contribute to a better understanding of coalification in the Alpine orogeny.

In this paper, new random vitrinite reflectance data are presented and the causes of random vitrinite reflectance variability in flysch sediments are discussed.

\section{GEOLOGICAL SETTING}

The Outer Carpathians belong to the European Alpine mountain chain that extends from the Iron Gate of the Danube River in the west to Predeal Pass in Romania (e.g., Książkiewicz, 1977; Birkenmajer, 1986; Oszczypko, 1992, 2006; Świerczewska and Tokarski, 1998). The Outer Carpathians are subdivided into western and eastern parts (e.g., Oszczypko, 2004; Fig.1A). To the south, there is the Pieniny Klippen Belt forming an orogenic suture between the Outer and Inner Carpathians. The Outer Carpathians, also known as the Flysch Carpathians, comprise Mesozoic, Paleogene and Neogene rock complexes which, from the Late Eocene to Middle Miocene, were tectonically deformed, separated from their basement, and thrust tens of kilometres northwards onto the foreland (e.g., Książkiewicz, 1972; Birkenmajer, 1986; Oszczypko, 1992; Ślączka, 1996; Oszczypko and Oszczypko-Clowes, 2014). In front of the Outer Carpathians, folded molasse sediments occur (Żelaźniewicz et al., 2011). 


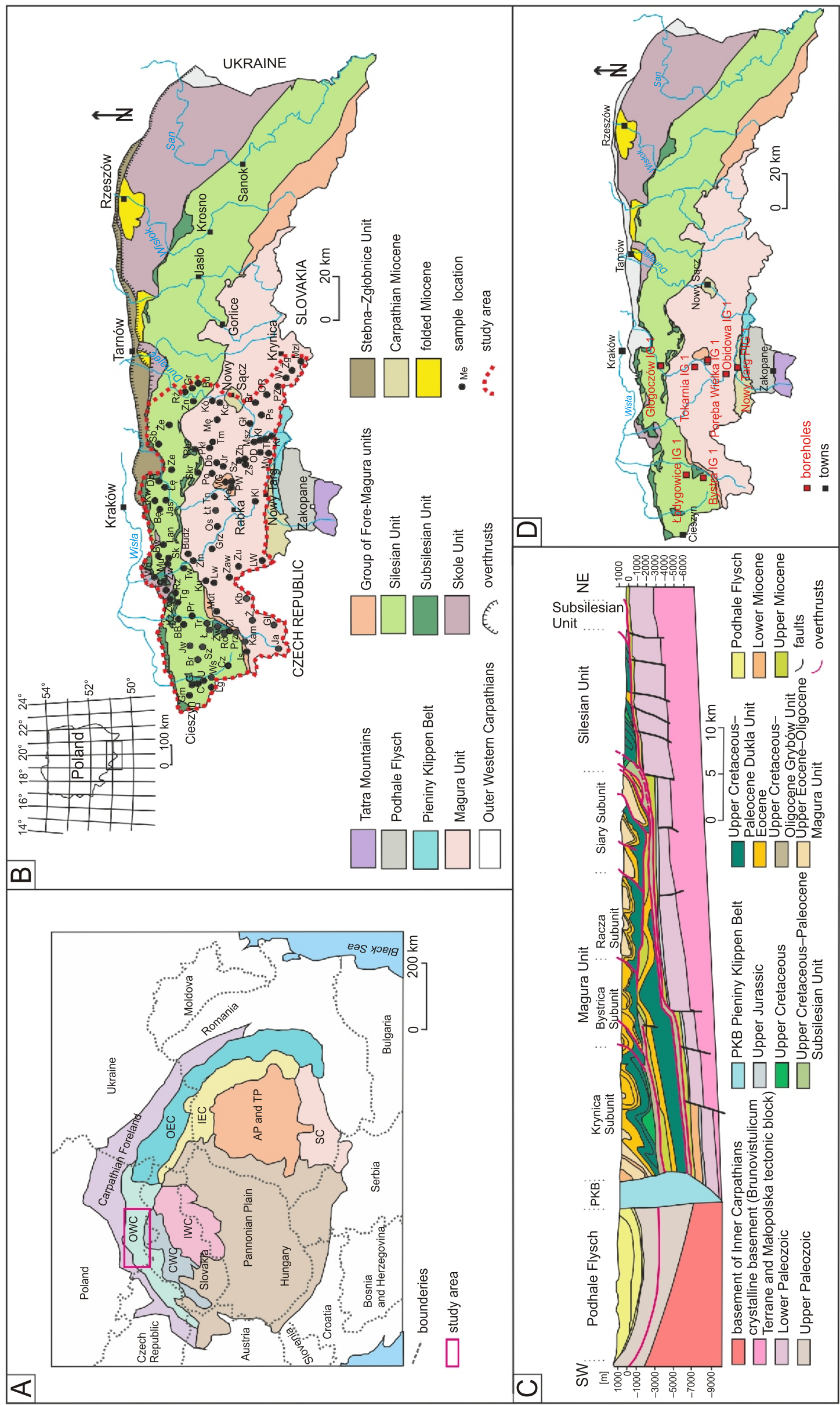

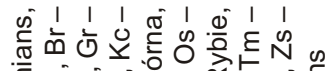

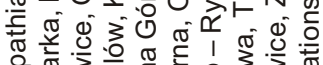

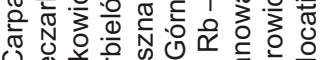

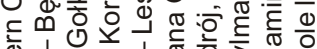

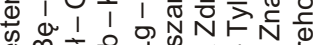

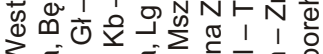
3 कீत

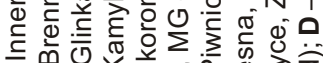

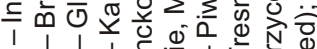

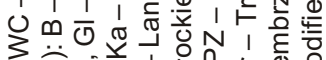
3 क्षे

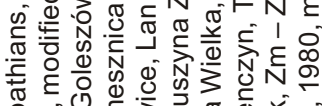

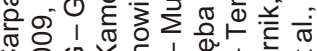

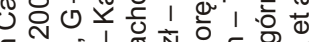

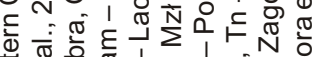
के ш

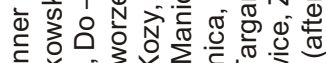

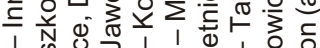
U. a क ब

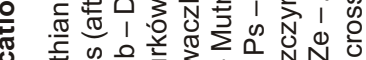

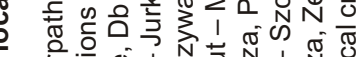

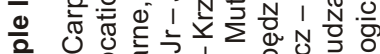
焉

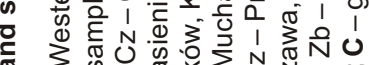

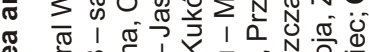

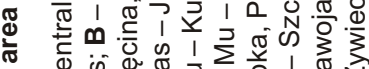

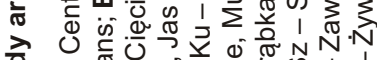
U. \& 3 这

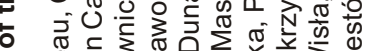

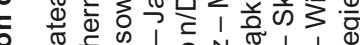

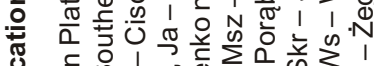
¿

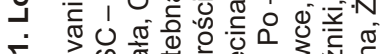

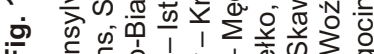
진.

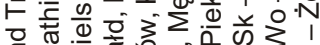

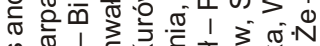
๑

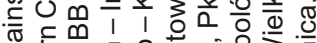

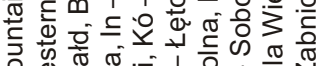
品

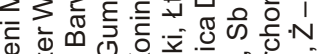

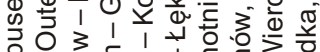

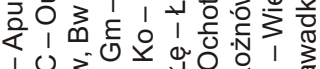
$1030 \times 0$

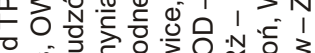
क ल

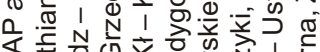

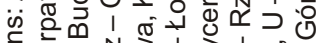
垔

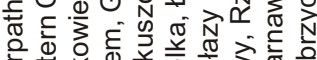

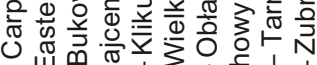

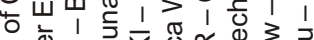

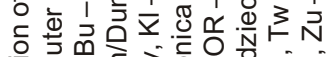
क्ष

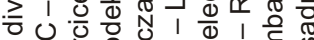

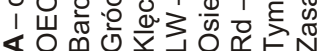


A number of structural units belonging to the Flysch Carpathians occur within the study area (Fig. 1B). Starting from the south, these are the Magura Unit, the group of Fore-Magura units and the Silesian and Subsilesian units (e.g., Golonka, 2007). The Fore-Magura units include the Fore-Magura Unit sensu stricto, and the Dukla and Grybów units occurring in tectonic windows (Fig. 1C). Below the nappes, there are Miocene formations and the crystalline basement of the European Platform belonging to the Brunovistulicum Upper Silesian Massif (also known as the Upper Silesian Block) and the Małopolska tectonic block (Paul et al., 1996; Żytko, 1999; Cieszkowski et al., 2009; Buła et al., 2015; Fig. 1C).

Each nappe is a separate tectonic unit composed mainly of turbiditic formations. Prior to any orogenic tectonism, the nappe sediments were accumulated in a series of sedimentary basins on the northern margin of the Tethys Ocean (Książkiewicz, 1972; Tokarski, 1980; Oszczypko and Ślączka, 1985; Konon, 2001; Nemčok et al., 2001). The individual basins were separated by a series of submarine uplifts and elevations. The most important of these, the Subsilesian, Silesian and Czorsztyn ridges, were the main sources of clastic material deposited in the various basins (Poprawa et al., 2002).

\section{METHODS}

\section{FIELD STUDIES}

The basic research material consisted of 205 flysch samples comprising 170 samples gathered at 85 surface locations and 35 samples from 7 boreholes. The surface samples came from natural outcrops and quarries (see Fig. 1B). Core samples were collected from boreholes: Tokarnia IG 1, Bystra IG 1 , Obidowa IG 1, Nowy Targ PIG 1, Łodygowice IG 1, Głogoczów IG 1 and Poręba Wielka IG 1. The borehole locations are shown on Figure 1D.

\section{ORGANIC MATTER SAMPLES}

Lump samples with polished surface were prepared from all collected samples. In this study, all lenticular and lamellar accumulations of coal, plant detritus and dispersed organic matter were treated as preserved organic material differing only in size. Only coalified organic matter coeval with flysch sediments was selected, no coal exotics included.

\section{VITRINITE REFLECTANCE}

To define the degree of organic-matter coalification, random vitrinite reflectance measurements $R_{r}^{\circ}$ were carried out. Reflectance is the ability of polished surfaces of macerals of the vitrinite and huminite groups to reflect light. Measurements of reflectance were made on surfaces of ulminite B/collotelinite in rocks containing vitrinite (ISO 7404-5:2009) in partially polarised light $(1 \mathrm{~N})$ using an Opton Zeiss microscope with Axioplan MPM 400 reflectometre, according to the ICCP (International Committee for Coal and Organic Petrology, 1994) requirements. Immersion oil with a refractive index of $n=1.518$ at a temperature of $20-22^{\circ} \mathrm{C}$, and the uranyl standard of $0.904 \%$ were used. The number of separate measurements per sample, ranging from $71-145$, depended on the number of measuring points, i.e. the amount of coalified collotelinite/vitrinite forms.
The maximum standard deviation of the random vitrinite reflectance measurements was calculated to be $0.06 \%$.

\section{RESULTS}

VARIABILITY OF DEGREE OF COALIFICATION OF PLANT MATERIAL IN INDIVIDUAL STRUCTURAL UNITS - SURFACE SAMPLES

The degree of coalification of allochthonous plant material varies throughout the entire profile of the Outer Western Carpathian formations (Appendix 1*). Organic matter maturity varies even between samples from the same lithostratigraphic unit.

Reflectograms based on the measured $R_{r}^{\circ}$ typically exhibit two or even three modal values (Fig. 2). The first peak is related to the occurrence of so-called dark vitrinite (vitrinite B) which lowers the real value of $R_{r}^{0}$ in the sample. Dark vitrinite reflects sub-impregnation with resinite material or an origin from non-lignine marine plants or even partial bituminisation of the plant material, e.g. in deep-sea conditions (Newman and Newman, 1982). The second peak should be related to collotelinite (vitrinite A). Usually, this peak is clearly separated from the others and is the dominant peak. With a standard registration for $1 / 2 \mathrm{~V}=0.05 \%$ (Stach et al., 1982), the two peaks link as one with a noticeable negative skewness (Syrek, 2009). Measurements made on pseudovitrinite, with petrographic features similar to collotelinite or vitrodetrinite, may result in a third peak.

Magura Unit. The degree of coalification of organic material in the Magura Unit shows a generally increasing trend towards the south (Fig. 3). The highest $R_{r}^{\circ}$ values characterize the area directly bordering the Pieniny Klippen Belt. Here, the $R_{r}^{\circ}$ values range from $0.71 \%$ in the Szczawnica Formation (Senonian-Paleocene) at Kościenko nad Dunajcem (Kr, MS 43; abbreviation of sample location and its symbol for all text see Fig. 3 and Appendix 1) to $0.81 \%$ in Maniowy (My, MS 109) and $0.82 \%$ in the Magura sandstones (Eocene-Oligocene) at Klikuszowa (KI, MS 130) near Nowy Targ (Table 1). The lowest $R_{r}^{\circ}$ values $(0.40-0.45 \%$; MS $96,60,06,151)$ typify the northern and central-eastern parts of the nappe. Poprawa et al. (2002) have shown that, in the southern part of the Magura Basin, the total thickness of Cretaceous and Paleogene sediments was 3000-3500 $\mathrm{m}$ and $2300-2500 \mathrm{~m}$ in the northern part in the study area. Subsidence from the end of the Cretaceous to Early Miocene may be attributed to flexural bending of the basement due to subduction, and to burial by the accretionary wedge (Poprawa et al., 2002).

The central parts of the Magura Unit, where tectonic windows are situated, also feature high values of $R_{r}^{\circ}$. In the Mszana Dolna (MG, MS 69, 87) tectonic window, organic matter in the Krosno Beds (Oligocene) of the Dukla Unit shows $R_{r}^{\circ}$ of $0.65-0.67 \%$. In the Grybów Marl Formation (Middle/Upper Eocene) of the Grybów Unit in Koninki (Ko, MS 56) the value is $0.64 \%$. In the Szczawa (Sz, MS 55) tectonic window, the $R_{r}^{\circ}$ values of coalified matter in the Krosno Beds (Oligocene) of the Grybów Unit are $0.64 \%$. In the Klęczany-Limanowa (Kc, MS $81)$ tectonic window, the $R_{r}^{\circ}$ values of organic matter in the Krosno Beds (Oligocene) and Cergowa Beds of the Grybów Unit (Peszat, 1997) are as high as 0.76\% (Table 1).

In the entire profile of the Magura Unit (Appendix 1), no correlation of $R_{r}^{\circ}$ with individual lithostratigraphic position was noted. The greatest diversity is seen in the Magura Formation (Lower Eocene-Oligocene) in which $R_{r}^{\circ}$ values range from 0.40 to $0.82 \%$ (Table 1$)$. 

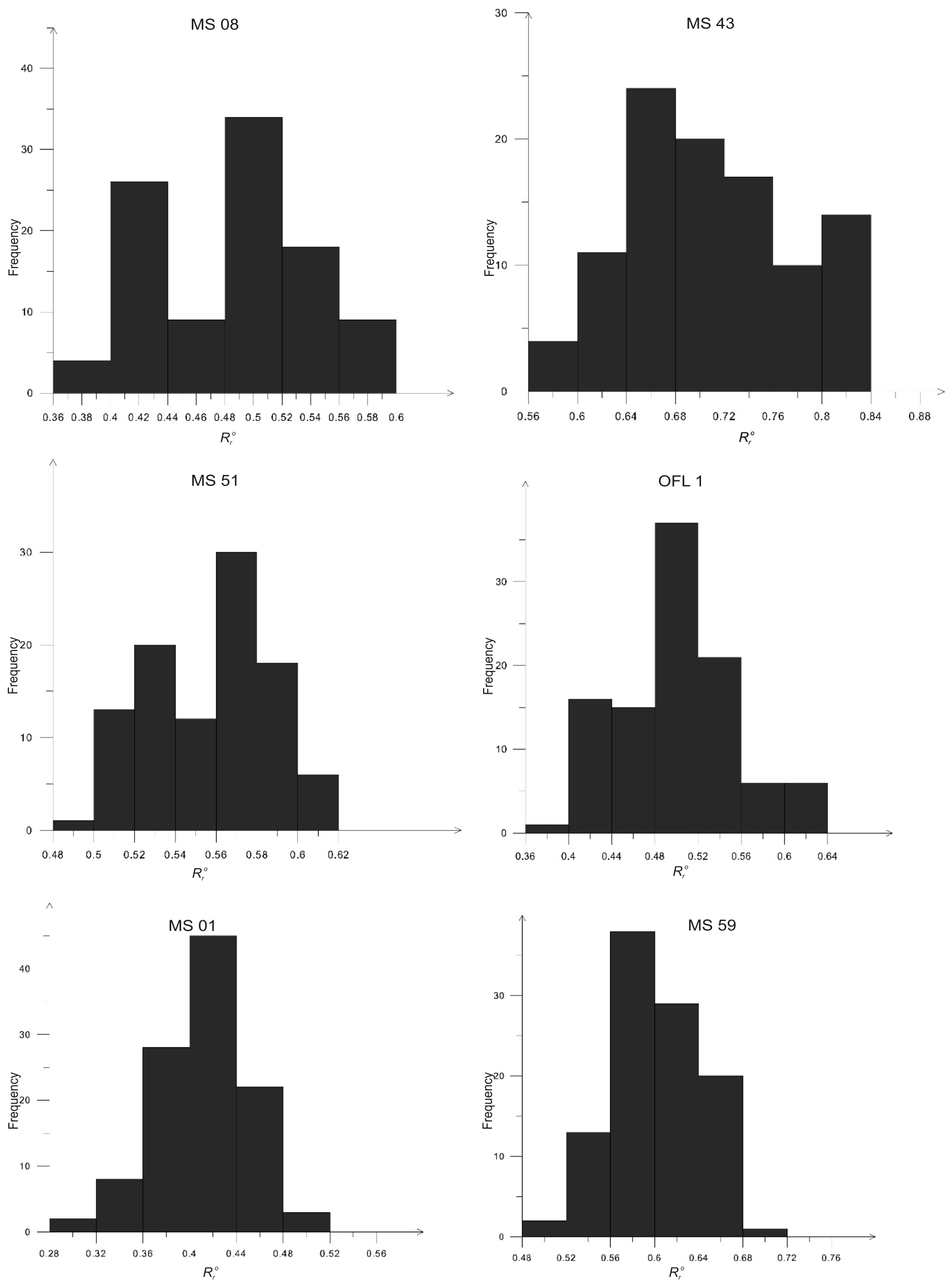

Fig. 2. Typical histograms of random vitrinite reflectance from selected samples 


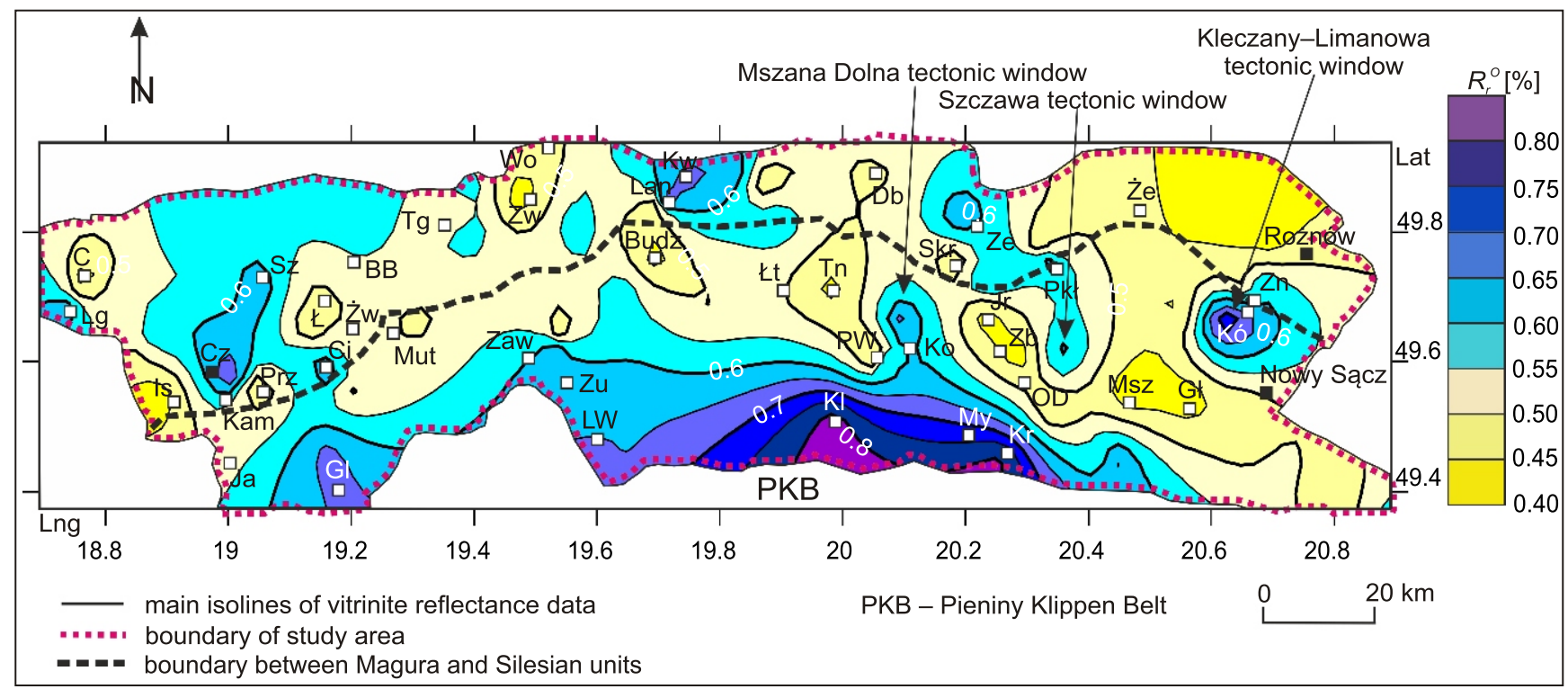

Fig. 3. Map of surface samples with random vitrinite reflectance variability within study area

\section{Other explanations as in Figure 1B}

Fore-Magura Unit sensu stricto. Most of the six samples from the Fore-Magura Unit s.S., collected in the areas of Istebna (Is), Kamesznica (Kam) and Przybędza/Juraszów (Prz), are from the Oligocene Krosno Beds in which $R_{r}^{\circ}$ ranges from 0.42 to $0.45 \%$; the degree of coalification is uniform. Interestingly, samples of the older Jaworzynka Formation (MS 174; Lower Senonian) taken in Cięcina $(\mathrm{Ci})$ are characterized by $R_{r}^{\circ}$ values of $0.81 \%$, and samples of the younger Oligocene Menilite beds (MS 187) from Przybędza/Juraszów (Prz; Table 1) by a value of $0.54 \%$. A correlation between $R_{r}^{\circ}$ values and stratigraphic age may be indicated. In this case, the difference in $R_{r}^{\circ}$ between the oldest and the youngest beds is $\sim 0.3 \%$, which is consistent with a trend of increasing $R_{r}^{\circ}$ with depth of burial (Hilt's law). Differentiating the northern and southern part of the Fore-Magura Unit (Golonka et al., 2005; Golonka, 2007), it is notable that the degree of coalification is higher in the lithostratigraphic profile of the southern unit that has features in common with Magura Unit formations, whereas it is lower in the northern part where lithology is similar to the Silesian Unit.

Silesian Unit. The trend in the area of Silesian Unit is not as well visible as in the Magura Unit; more diversity within $R_{r}^{\circ}$ is observed. A map of the distribution of $R_{r}^{o}$ shows four areas with elevated values (Fig. 3). In the western part of the Silesian Unit, the highest value of $0.73 \%$ was noted in the Istebna Beds (Senonian-Paleocene) in the area of Kamesznica (Kam, MS 178 ), values of $0.72 \%$ in the Godula Beds (Cenomanian-Senonian) in Szczyrk (Szcz, MS 131), and of $0.63 \%$ in the Cieszyn Limestones Formation (Tithonian-Berriasian) in Leszna Górna (Lg, MS 119).

In the central part of the unit, the highest $R_{r}^{0}$ values appeared in samples from the Lanckorona (Lan, MS 157, MS 183) area, namely $0.62 \%$ from the Lhoty Formation (Albian-Cenomanian), $0.69 \%$ from the Veřovice Formation (Barremian-Aptian), and $0.64 \%$ from an outcrop of the Veřovice Formation in Krzywaczka (Kw, MS 142). The eastern part of the Silesian Unit has two zones of relatively high $R_{r}^{\circ}$. The first involves organic matter in the Istebna Formation (Senonian/Paleocene) from Zegartowice (Ze, MS 47) with $R_{r}^{\circ}$ values of $0.65 \%$. The second zone is near Rożnów Lake in Znamirowice (Zn, MS 53; Istebna Formation) and Kurów (Kó, MS 168; Cisownica Shale; Valanginian/Hauterivian) with $R_{r}^{\circ}$ values of $0.64 \%$ and $0.63 \%$, respectively.

In the entire profile of the Silesian Unit, there is no correlation between organic matter maturity and the age of particular lithostratigraphic beds. The greatest diversity of $R_{r}^{0}$ is visible within the Godula (Cenomanian-Senonian), Istebna (Senonian-Paleocene) and Krosno (Oligocene) formations. The lowest and highest values in these formations differ by $0.20 \%, 0.33 \%$ and $0.17 \%$, respectively.

Subsilesian Unit. Samples were collected from the Żywiec $(\dot{Z} w)$ tectonic window and the tectonically disturbed Lanckorona-Żegocina area (Fig. 3).

The Żegocina Marls (Senonian) gave the highest value $(0.63 \%)$ of $R_{r}^{\circ}$ of all tested Subsilesian samples, and the Menilite Formation (Oligocene), the lowest $(0.46 \%$; Table 1$)$. Generally, the degree of coalification in the Subsilesian Unit is rather uniform (see Appendix 1). The exceptional $R_{r}^{0}$ value of $0.63 \%$ from the Żegocina Marls may reflect the fact that the marls comprise re-deposited blocks of Frydek-type marls from the limestone platform and occur in an area of tectonic melanges (Jugowiec-Nazarkiewicz and Jankowski, 2001).

VARIABILITY OF DEGREE OF COALIFICATION OF ORGANIC MATERIAL IN BOREHOLES

In the southernmost borehole of Nowy Targ PIG $1, R_{r}^{\circ}$ increases with depth (Fig. 4), attaining a value of $0.61 \%$ at a depth of $100 \mathrm{~m}, 0.63 \%$ at $800 \mathrm{~m}$, and $0.67 \%$ at $2150 \mathrm{~m}$. This small increase in $R_{r}^{\circ}$ occurs entirely within the Malcov Beds (Magura Formation). A greater increase to $0.75 \%$ is evident at $\sim 2500 \mathrm{~m}$ in the older Szczawnica Formation.

Three structural units were encountered in the Obidowa IG 1 borehole (Fig. 4): the Magura Unit down to $2666 \mathrm{~m}$, and the Grybów Unit at $\sim 2800 \mathrm{~m}$, which passes at $\sim 3300 \mathrm{~m}$ into the Obidowa-Słopnice Unit that continues down to $4570.5 \mathrm{~m}$. The status of the Obidowa-Słopnice Unit is problematic. It is 
Vitrinite reflectance of organic matter in the OWC formations and beds

\begin{tabular}{|c|c|c|c|c|c|c|}
\hline \multirow{2}{*}{$\begin{array}{l}\text { Name of } \\
\text { lithostratigraphic } \\
\text { unit }\end{array}$} & \multirow{2}{*}{ Age } & \multirow{2}{*}{$\begin{array}{l}\text { Structural } \\
\text { unit }\end{array}$} & $\begin{array}{l}\text { Minimum } \\
\text { value }\end{array}$ & $\begin{array}{l}\text { Maximum } \\
\text { value }\end{array}$ & $\begin{array}{c}\text { Number of } \\
\text { measurements }\end{array}$ & \multirow{2}{*}{ Sample symbol } \\
\hline & & & \multicolumn{3}{|c|}{ of $R_{r}^{\circ}$ in particular lithostratigraphic unit } & \\
\hline $\begin{array}{l}\text { Jaworzynka } \\
\text { Formation }\end{array}$ & $\begin{array}{l}\text { Senonian- } \\
\text { Paleocene }\end{array}$ & Magura & 0.40 & 0.49 & 2 & MS 96 (Ja), 99 (Mut) \\
\hline $\begin{array}{l}\text { Ropianka } \\
\text { Formation }\end{array}$ & $\begin{array}{l}\text { Senonian- } \\
\text { Paleocene }\end{array}$ & Magura & 0.40 & 0.64 & 4 & MS $60(P W), 91(\mathrm{Zu}), 189,190$ \\
\hline $\begin{array}{l}\text { Szczawnica } \\
\text { Formation }\end{array}$ & $\begin{array}{l}\text { Senonian- } \\
\text { Paleocene }\end{array}$ & Magura & 0.43 & 0.81 & 6 & MS 43, 58 (OD), 67, 79, 83, 109 (My) \\
\hline $\begin{array}{l}\text { Beloveza } \\
\text { Formation }\end{array}$ & $\begin{array}{l}\text { Lower } \\
\text { Eocene }\end{array}$ & Magura & 0.43 & 0.65 & 12 & $\begin{array}{c}\text { MS 38, 41, 46, 51, } 50(\mathrm{Zb}), 71,97,76 \\
(\mathrm{Pkł}), 102,108,111,120\end{array}$ \\
\hline $\begin{array}{l}\text { Hieroglyphic } \\
\text { Beds }\end{array}$ & Eocene & Magura & 0.51 & 0.65 & 6 & $\begin{array}{c}\text { MS 35, } 61 \text { (Zaw), } 93 \text { (Zaw), 95, } 105 \text { (Łt), } \\
\text { 116, }\end{array}$ \\
\hline $\begin{array}{l}\text { Łącko } \\
\text { Formation }\end{array}$ & Eocene & Magura & 0.41 & 0.43 & 2 & MS 57 (Gł), 151 (Msz) \\
\hline $\begin{array}{l}\text { Zarzecze } \\
\text { Formation }\end{array}$ & Eocene & Magura & 0.48 & 0.60 & 2 & OFL 23; MS 84 \\
\hline $\begin{array}{l}\text { Magura } \\
\text { Formation }\end{array}$ & $\begin{array}{l}\text { Eocene- } \\
\text { Oligocene }\end{array}$ & Magura & 0.40 & 0.82 & 27 & 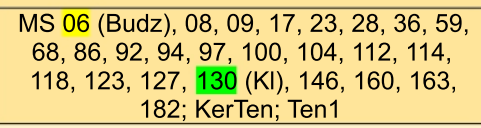 \\
\hline $\begin{array}{l}\text { Jaworzynka } \\
\text { Formation }\end{array}$ & $\begin{array}{l}\text { Upper } \\
\text { Senonian }\end{array}$ & $\begin{array}{c}\text { Fore-Magura } \\
\text { s.s. }\end{array}$ & \multicolumn{2}{|c|}{0.91} & 1 & MS 174 \\
\hline $\begin{array}{l}\text { Menilite } \\
\text { Formation } \\
\end{array}$ & $\begin{array}{l}\text { Upper } \\
\text { Eocene }\end{array}$ & $\begin{array}{c}\text { Fore-Magura } \\
\text { s.s. }\end{array}$ & \multicolumn{2}{|c|}{0.54} & 1 & MS 187 \\
\hline $\begin{array}{l}\text { Krosno } \\
\text { Formation }\end{array}$ & Oligocene & $\begin{array}{l}\text { Fore-Magura } \\
\text { s.s. }\end{array}$ & 0.42 & 0.45 & 4 & MS 01 (Kam), 04, 14, 117 \\
\hline $\begin{array}{l}\text { Grybów } \\
\text { Formation }\end{array}$ & $\begin{array}{l}\text { Middle/Upper } \\
\text { Eocene }\end{array}$ & Fore-Magura & 0.42 & 0.64 & 2 & MS 52 (Sz), 56 (Ko) \\
\hline $\begin{array}{l}\text { Krosno } \\
\text { Formation }\end{array}$ & Oligocene & Fore-Magura & 0.58 & 0.76 & 5 & $\mathrm{MS}, 38,55(\mathrm{Sz}), 69,81(\mathrm{Kc}), 87$ \\
\hline $\begin{array}{l}\text { Vendryně } \\
\text { Formation }\end{array}$ & Tithonian & Silesian & \multicolumn{2}{|c|}{0.55} & 1 & MS 22 \\
\hline $\begin{array}{l}\text { Cieszyn } \\
\text { Limestones }\end{array}$ & $\begin{array}{l}\text { Tithonian- } \\
\text { Berriasian }\end{array}$ & Silesian & 0.51 & 0.63 & 4 & MS $30(G), 115,119(\mathrm{Lg}), 175$ \\
\hline $\begin{array}{l}\text { Cisownica } \\
\text { Shales }\end{array}$ & $\begin{array}{c}\text { Valanginian- } \\
\text { Hauterivian }\end{array}$ & Silesian & 0.40 & 0.64 & 2 & MS 32 (C), 168 (Kó) \\
\hline $\begin{array}{l}\text { Grodziszcze } \\
\text { Formation }\end{array}$ & $\begin{array}{l}\text { Hauterivian- } \\
\text { Aptian }\end{array}$ & Silesian & 0.46 & 0.56 & 4 & MS 16 (BB), 66, 40; OFL 19 (Wo) \\
\hline $\begin{array}{l}\text { Veřovice } \\
\text { Formation }\end{array}$ & $\begin{array}{l}\text { Barremian- } \\
\text { Aptian }\end{array}$ & Silesian & 0.51 & 0.69 & 5 & MS 33 (Zg), 142, 150, 166, 183 (Lan) \\
\hline Lhoty Formation & $\begin{array}{c}\text { Albian- } \\
\text { Cenomanian }\end{array}$ & Silesian & 0.50 & 0.62 & 7 & 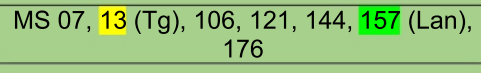 \\
\hline $\begin{array}{l}\text { Radiolarian } \\
\text { Beds }\end{array}$ & Cenomanian & Silesian & \multicolumn{2}{|c|}{0.48} & 1 & MS 155 \\
\hline $\begin{array}{l}\text { Godula } \\
\text { Formation }\end{array}$ & $\begin{array}{c}\text { Cenomanian- } \\
\text { Senonian }\end{array}$ & Silesian & 0.52 & 0.72 & 7 & $\begin{array}{c}\text { MS } 02 \text { (Ws), 11, 15, } 31(\mathrm{U}), 37,101,131 \\
(\mathrm{Szcz})\end{array}$ \\
\hline $\begin{array}{l}\text { Variegated } \\
\text { Shales }\end{array}$ & Maastrichtian & Silesian & 0.41 & 0.58 & 2 & MS $164(Z w), 162(Z w)$ \\
\hline $\begin{array}{l}\text { Istebna } \\
\text { Formation }\end{array}$ & $\begin{array}{l}\text { Senonian- } \\
\text { Paleocene }\end{array}$ & Silesian & 0.40 & 0.73 & 14 & $\begin{array}{c}\text { MS } 18,20,26,21,25(\mathrm{Db}), 27,34,45,47 \\
53,141,143,178 \text { (Kam); OFL } 32\end{array}$ \\
\hline $\begin{array}{l}\text { Hieroglyphic } \\
\text { Beds }\end{array}$ & $\begin{array}{l}\text { Middle } \\
\text { Eocene }\end{array}$ & Silesian & 0.55 & 0.60 & 2 & MS 05 (Kam), 179 (Kam) \\
\hline $\begin{array}{l}\text { Globigerina } \\
\text { Marls }\end{array}$ & $\begin{array}{l}\text { Upper } \\
\text { Eocene }\end{array}$ & Silesian & \multicolumn{2}{|c|}{0.48} & 1 & MS 137 \\
\hline $\begin{array}{l}\text { Menilite } \\
\text { Formation }\end{array}$ & $\begin{array}{l}\text { Eocene- } \\
\text { Oligocene }\end{array}$ & Silesian & 0.40 & 0.53 & 3 & MS 72, 90 (Skr), 125 (Zn) \\
\hline $\begin{array}{l}\text { Krosno } \\
\text { Formation }\end{array}$ & Oligocene & Silesian & 0.46 & 0.63 & 10 & $\begin{array}{c}\text { MS 12; MS } 29 \text { (Ł), 5, MS 165W, MS } \\
\text { 165D; MS 169, } 139 \text { (Zn), Sk14W, 15MuW, } \\
\text { OFL1 }\end{array}$ \\
\hline $\begin{array}{l}\text { Cisownica } \\
\text { Shales }\end{array}$ & Valanginian & Subsilesian & 0.46 & 0.49 & 2 & MS $140(\dot{Z} w), 177(R b)$ \\
\hline $\begin{array}{l}\text { Veřovice } \\
\text { Formation }\end{array}$ & $\begin{array}{l}\text { Barremian- } \\
\text { Aptian }\end{array}$ & Subsilesian & \multicolumn{2}{|c|}{0.50} & 1 & MS 170 \\
\hline Frydek Marls & Senonian & Subsilesian & \multicolumn{2}{|c|}{0.49} & 1 & MS 44 \\
\hline Żegocina Marls & Senonian & Subsilesian & \multicolumn{2}{|c|}{0.63} & 1 & MS 39 \\
\hline $\begin{array}{l}\text { Szydłowiec } \\
\text { Sandstones }\end{array}$ & $\begin{array}{l}\text { Upper } \\
\text { Senonian }\end{array}$ & Subsilesian & \multicolumn{2}{|c|}{0.48} & 1 & MS 173 \\
\hline Menilite & Eocene & Subsilesian & \multicolumn{2}{|c|}{0.46} & 1 & MS 172 \\
\hline $\begin{array}{l}\text { Krosno } \\
\text { Formation }\end{array}$ & Oligocene & Subsilesian & \multicolumn{2}{|c|}{0.52} & 1 & MS 171 \\
\hline
\end{tabular}

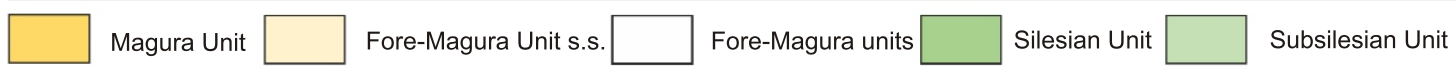

$\square$ highest value of $R_{r}^{\circ} \square$ lowest value of $R_{r}^{\circ}$ 

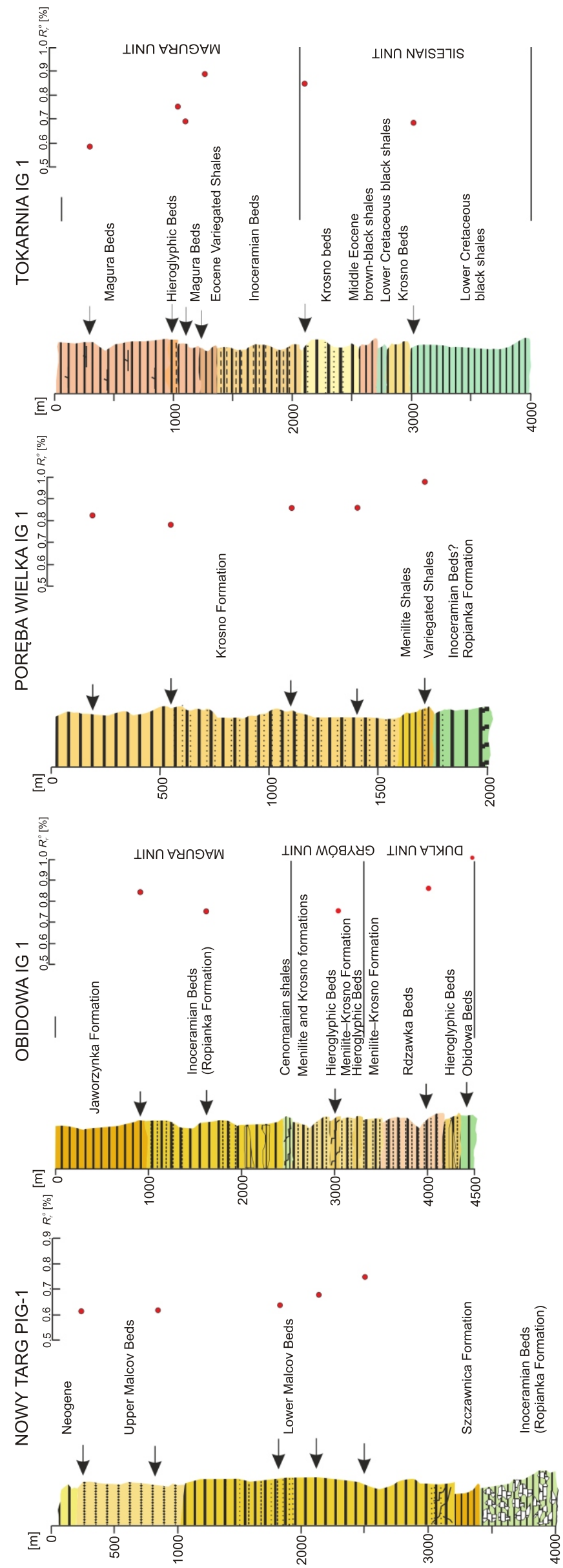
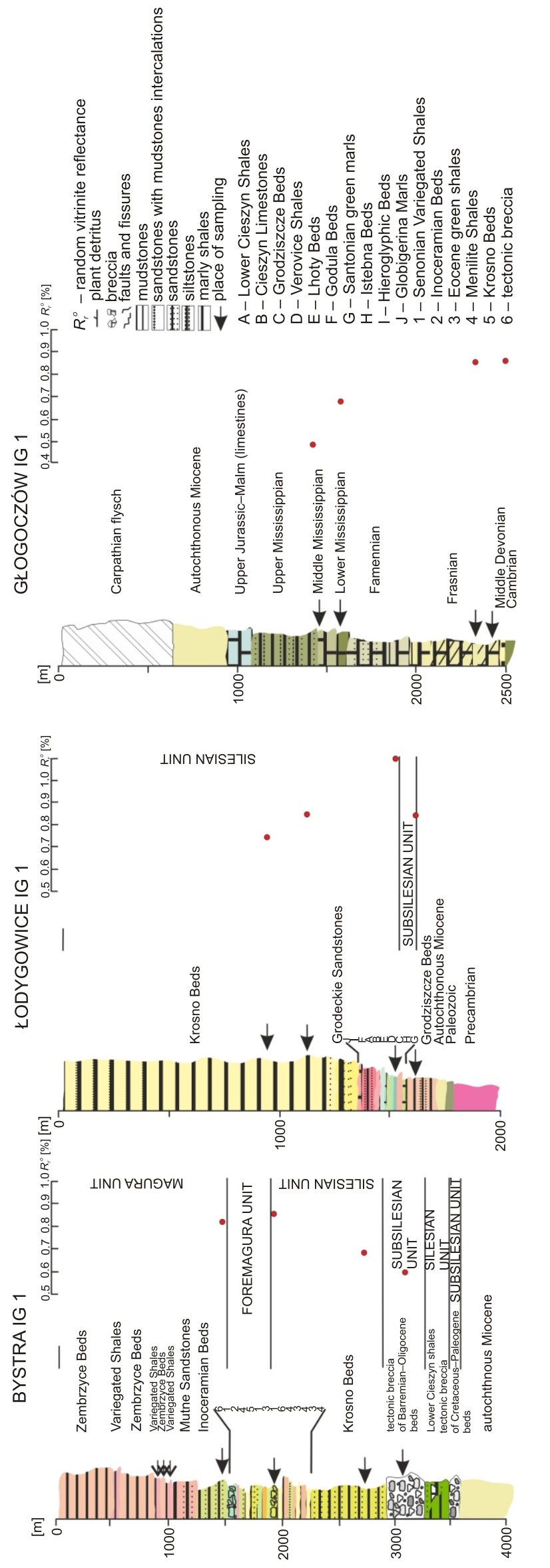
deemed to be a western facies extension of the Dukla Unit (Burtan et al., 1992) and even as a part of the Skole Unit (Żytko and Malata, 2001). For lithostratigraphic reasons, a linkage to the Dukla Unit is favoured here.

In general, $R_{r}^{\circ}$ values increase with depth from $0.76 \%$ in the Inoceramian Beds of the Magura Unit to $1.02 \%$ in the Inoceramian (Obidowa) Beds of the Dukla Unit. Deviations from the trend are evident in younger beds of other structural units in the overthrust area.

Samples from the Poręba Wielka IG 1 borehole represent the Dukla Unit flysch formations from the Mszana Dolna tectonic window (Fig. 4). The rocks were deposited in relatively shallow water (Jugowiec-Nazarkiewicz and Jankowski, 2001). Silty zones, more susceptible to compression, show greater inclinations. The youngest sediments, the Krosno Formation, were drilled to a depth of $1500 \mathrm{~m}$. The $R_{r}^{\circ}$ value of organic matter in the upper part of the Krosno Formation at a depth of $200 \mathrm{~m}$ is $0.82 \%$. $R_{r}{ }^{\circ}$ values of organic matter in lower part of Krosno sediments range from $0.79 \%$ at $\sim 500 \mathrm{~m}$ to $0.86 \%$ at $1100 \mathrm{~m}$. The $R_{r}{ }^{\circ}$ value obtained from the Menilite Formation at $1420-1423 \mathrm{~m}$ is $0.86 \%$, and from the Inoceramian Beds (Ropianka Formation) at $1744-1747 \mathrm{~m}-0.97 \% . R_{r}^{o}$ values increase with depth.

In the Tokarnia IG 1 borehole, sediments from the Magura and Silesian units were sampled (Fig. 4). The $R_{r}^{\circ}$ of organic matter in the Magura Formation at the lowest depth in profile is $0.59 \%$. An increase to $0.76 \%$ with increasing depth is observed in the Hieroglyphic Beds. Below, a decrease to $0.68 \%$ is related to the reappearance of the Magura Formation, most likely in a fold.

At $2044 \mathrm{~m}$ depth, the Inoceramian Beds from the older Magura Unit are thrust over the Krosno Formation from the younger Silesian Unit. The random vitrinite reflectance for the Krosno Formation (Oligocene) is $0.79 \%$, lower by $0.08 \%$ than for the overlying beds ( $0.88 \%$ in Eocene shales). Organic matter in deeper sediments shows a slight increase in $R_{r}^{\circ}$ to $0.84 \%$. Below, it decreases $(0.67 \%)$ in marly shales that probably represent the Cisownica shale. In this instance, the decrease may be related to a tectonic unconformity between the Oligocene Krosno Formation and the Lower Cretaceous shales.

Sediments in the Bystra IG 1 borehole show the greatest lithostratigraphic variability of all in the boreholes (Fig. 4). Folding is important; alternating older and younger horizons are often encountered in profiles of known lithostratigraphic units. There, where the Fore-Magura Unit is thrust over the Magura Unit, the $R_{r}^{\circ}$ of organic matter measured in the Inoceramian Beds (Upper Senonian) is $0.82 \%$, whereas near the overthrust of the Fore-Magura Unit onto the Silesian Unit, the value is $0.86 \%$ in the Krosno Formation (Oligocene). Decreases in $R_{r}^{\circ}$ to $0.68 \%$ were noted in the Krosno Beds in the overthrust of the Silesian Unit on the Subsilesian Unit, and to $0.60 \%$ in tectonic breccia in the overthrust of the Subsilesian Unit on the Silesian Unit $(0.60 \%)$. The variation ("jumps") in $R_{r}^{o}$ in the profile seems to reflect numerous fold-type tectonic structures and could indicate that organic matter in the flysch sediments had reached final maturity prior to final thrusting. Otherwise, "jumps" could not be visible within tectonic structures.

Sediments from the Łodygowice IG 1 borehole represent both the Silesian Unit and the Subsilesian Unit. Below, autochthonous Miocene rocks and crystalline basement were drilled (Fig. 4). $R_{r}^{\circ}$ values of organic matter in the Silesian Unit increase with depth. The lowest value of $R_{r}^{\circ}(0.74 \%)$ was measured in the Krosno Formation (Oligocene), the highest (1.19\%) in the Grodziszcze Formation (Hauterivian-Aptian, Subsilesian Unit). In the overthrust area, a distinct decrease of $R_{r}^{\circ}$ to $0.83 \%$, evident in the Grodziszcze Formation, may reflect small-scale, thrust-related lihological complexity between structural units.
The northernmost borehole of Głogoczów IG 1 penetrates flysch formations to a depth of $652.5 \mathrm{~m}$. The flysch formations comprise the Silesian Unit (to $601 \mathrm{~m}$ depth) and the Subsilesian Unit (to $652.5 \mathrm{~m}$ ). They are both tectonically disturbed. Within the Silesian Unit, the Grodziszcze Formation (Hauterivian/Barremian) passes down into the Lhoty Formation (Albian) and the Upper Istebna Formation (Paleocene). The tectonically mixed formations of the Subsilesian Unit might be termed a tectonic breccia (Fig. 4). Reversed beds in the Silesian Unit reflect significant folding and overthrusting. These rocks may belong to the northern margin of the Flysch Carpathians where internal units are thrust over highly-tectonized rocks of the Subsilesian Unit. Sampling was not possible here. In this core, the $R_{r}{ }^{\circ}$ value increases from $0.48 \%$ in the Upper Visean Shales to $0.65 \%$ in Lower Visean carbonate formations, and $0.85 \%$ in Devonian formations. Organic matter in Mississippian rocks at a depth of $\sim 1500 \mathrm{~m}$ is characterized by a relatively low degree of coalification.

\section{DISCUSSION}

\section{COMPARISONS WITH ORGANIC MATERIAL IN COEVAL SEDIMENTS} ELSEWHERE,BASED ON $R_{r}^{\circ}$ DATA

Degrees of coalification of organic matter in the Outer Carpathians relate to the sedimentary and tectonic history of the host rocks. To gain a more complete insight, comparisons are made to the eastern part of the Carpathians in Poland, the Podhale Flysch, the Carpathians outside Poland, and the Alps. The name Outer Western Carpathians (OWC) refers to the study area.

\section{EASTERN CARPATHIANS IN POLAND}

Relevant studies in the Eastern Carpathians involve mainly thick complexes of Lower Cretaceous shale series, Upper Cretaceous-Lower Oligocene silty sediments, and the Oligocene Krosno Formation (Matyasik, 1994; Semyrka, 2009). The focus of these studies was the hydrocarbon potential of the named formations, as the eastern Outer Carpathians are more favourably predisposed to develop effective oil systems (Kuśmierek, 2004). The lithostratigraphic similarity of the flysch formations in the Eastern and Outer Western Carpathians, and published vitrinite reflectance data, invite a comparison to be made.

The greatest amount of data on organic matter coalification is available for the Menilite Shales. Kosakowski et al. (2009) documented the low (from 0.35 to $0.40 \%$ ) degree of coalification in the Menilite Formation of the Dukla, Silesian and Skole units; the lowest $R_{r}^{\circ}$ values $(0.30 \%)$ were noted in the northwestern part of the Skole Unit, and the highest (up to $0.67 \%$ ) in the Dukla Unit in the southeastern part of the area. The increasing degree of coalification towards internal units of the Carpathians confirms earlier findings by Kruge et al. (1996) and Besserau et al. (1997).

Uniformly low $(<0.50 \%)$ values of $R_{r}^{o}$ characterizing the Menilite Shales inhibited estimation of gradient variability in surface samples (Kuśmierek, 1995). Those samples collected from significantly eroded elevation zones did not help. The older rocks provided more varied and more useful values. The fact that $R_{r}^{\circ}$ curves for the marginal zones of the Eastern Carpathian basin were mainly steeper than those for the central zones reflected, according to Kuśmierek (1990, 1995), the more stable tectonic regime of the marginal zones, and a delay in the process of burial that aided the estimation of maximal 
palaeo-heat flows. In addition, depth profiles of $R_{r}^{\circ}$ values in Oligocene formations from the Dwernik-3 and Sękowa-Gorlice boreholes (Eastern Outer Carpathians) are compatible with the trend of increasing degree of coalification with increasing depth. In some boreholes, upper beds are characterized by higher $R_{r}^{\circ}$ values than are lower beds in the profile. This is a distinguishing feature of highly-folded complexes and reversed stratigraphic series as well as of normally-deposited series of the Magura Nappe foreground or in its tectonic windows. Additionally, in very deep boreholes (e.g., Kuźmina-1 in the Bieszczady Mts.) that penetrated the basement, a lowering of $R_{r}^{0}$ in thrust slices of Upper Cretaceous rocks in the lower parts of the profile was previously noted (Borys et al., 1989; Semyrka, 2009). Decreases in $R_{r}^{o}$ is a consequence of deep tectonic slippage of the East European Platform with the result that formations now directly in contact with the basement occur at depths exceeding those at which their pre-tectonic $R_{r}^{o}$ values were established (Kuśmierek, 1990, 1995).

Similar patterns of differences in random vitrinite reflectance characterize the OWC area. Firstly, low values of $R_{r}^{\circ}(0.40-0.53 \%)$ from the Menilite Formation confirm the results of Kuśmierek (1995) and Kosakowski et al., (2009). Secondly, some borehole profiles provide further similar evidence. In the Tokarnia IG 1 borehole, higher $R_{r}^{\circ}$ values in the upper part of the profile are due to stratigraphic inversion and, in the
Poręba Wielka IG 1 borehole, to thrust slicing of the older Krosno Formation. In the Głogoczów IG 1, Łodygowice IG 1 and Tokarnia IG 1 boreholes that penetrated the basement, $R_{r}^{\circ}$ decreases at the contact of the flysch series with the basement. Finally, $R_{r}^{\circ}$ curves in the Nowy Targ PIG 1 and Obidowa IG 1 boreholes in the marginal zone of the Magura Unit (Fig. 5) are steeper than in other profiles.

Higher values of $R_{r}^{o}$ in the Magura Unit tectonic windows are represented by values from the Mszana Dolna, Klecczany and Szczawa sample locations which sediments belong to the Fore-Magura Unit. Oligocene formations, exposed in central zones, are characterized by higher $R_{r}^{o}$ than the older, surrounding rocks. Such anomalies are attributable to development of duplexes in the basement of the Magura Nappe in the final stage of its overthrusting onto the Carpathian Foredeep (Świerczewska and Tokarski, 1998; Świerczewska, 2005). According to Świerczewska (2005), heating related to tectonic burial was the main factor that influenced the Magura Unit strata. Such conditions were established during accretion.

The similarities in the $R_{r}^{o}$ patterns of the western and eastern parts of the Outer Carpathians seem to reflect consistently similar causes; both parts were subject to similar fluctuations during the syn- and post-orogenic stages of uplift and subsidence in the flysch sub-basins. Differences may be due to variations in sub-basin depths, degrees of subsidence, and late tectonism.

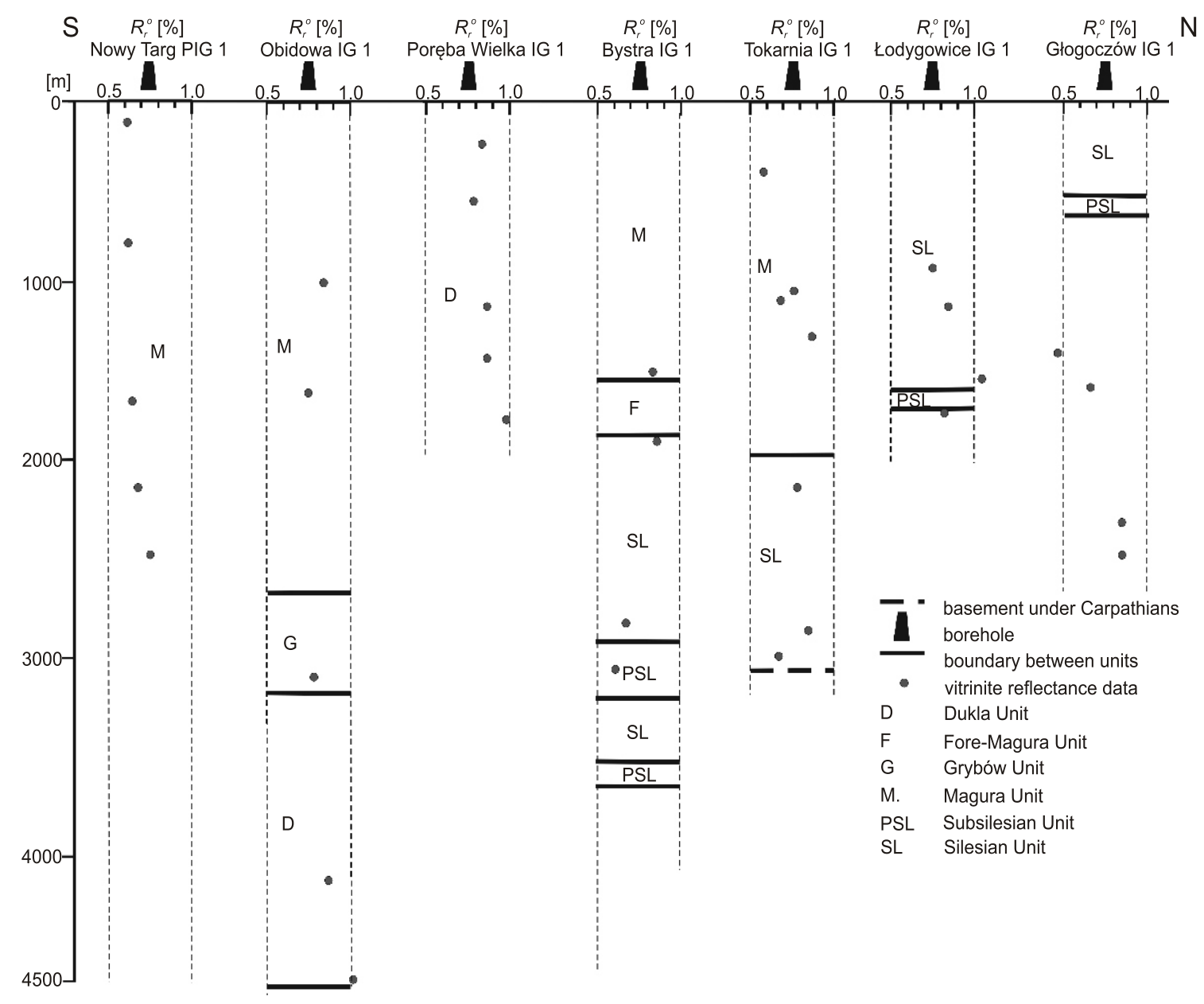

Fig. 5. Comparison of random vitrinte reflectance data in boreholes profiles in $\mathrm{N}-\mathrm{S}$ cross-section 


\section{PODHALE FLYSCH}

Variations in the degree of coalification in the Podhale Flysch are similar to those encountered in the OWC. However, the rank changes in the Podhale Flysch have not been fully described yet. Earlier work has focused on, e.g. macroscopic description and sedimentation of organic material. In their study of the thermal history of the Tatra Mts, Poprawa et al. (2004) used samples from the Podhale Flysch; typical $R_{r}^{0}$ values ranged from 0.85 to $1.3 \%$. Marynowski and Gawęda (2005), in a comparative analysis of biomarkers and $R_{r}^{\circ}$ in the Podhale Flysch Paleogene rocks, found that $R_{r}^{0}$ increases towards the SE, perpendicular to the main fault zones. The highest values were recorded in the Zakopane IG 1 borehole (2.37-2.42\%) and the Bukowina Tatrzańska IG 1 borehole (1.09-1.14\%), and the lowest in the Chochołów PIG 1 borehole $(0.78-1.02 \%)$. Later, the diagenesis, subsidence and thermal history of the Podhale Flysch were discussed (Kepinska, 2006; Środoń et al., 2006 Środoń, 2008). Wagner $(2010,2011)$ attempted to explain possible causes for the differences in organic matter rank, using $R_{r}{ }^{\circ}$ data from surface samples. He reported an increase in $R_{r}^{\circ}$ from the north-west $(0.49 \%)$ towards the south-east $(1.00 \%)$. These values correspond to bituminous coal D and C (PN-ISO 11760:2007/DIS 11760).

According to previous research, differences in $R_{r}^{\circ}$ values do not relate to the stratigraphy of the Podhale Flysch, but rather to the depth of burial of the sediments and later tectonic uplifts (Savian Phase). Furthermore, the changes in $R_{r}^{\circ}$ values track the contents of crystalline illite in silty rocks (Środoń, 2008). Crystalline illite contents indicate a clear trend of increasing temperature with depth of burial towards the SW. Wagner $(2010,2011)$ estimated the probable sediment burial depths in the region, assuming the values of palaeothermal gradient in the range of $30-40^{\circ} \mathrm{C} / \mathrm{km}$. Using the measured $R_{r}^{\circ}$, he calculated the depths from $3.2 \mathrm{~km}$ (gradient $30^{\circ} \mathrm{C} / \mathrm{km}$ ) to $2.7 \mathrm{~km}$ (gradient $\left.40^{\circ} \mathrm{C} / \mathrm{km}\right)$ in the northwestern part, and $\sim 5 \mathrm{~km}\left(30^{\circ} \mathrm{C} / \mathrm{km}\right)$ or $\sim 4 \mathrm{~km}\left(40^{\circ} \mathrm{C} / \mathrm{km}\right)$ in the south-east. These estimates suggest a flysch thickness greater than present-day thicknesses by $\sim 2.8 \mathrm{~km}$ in the north-west and $\sim 2.2 \mathrm{~km}$ in the south-east.

Both the OWC and the Podhale Flysch show a similar increase in $R_{r}^{\circ}$ towards the $S$ and SE. Differences are mainly evident in the ranges of $R_{r}{ }^{\circ}$ values both in surface and borehole samples in these areas. Surface values in the ranges of 0.49-1.00\% (Wagner, 2010, 2011) and 0.85-1.30\% (Poprawa et al., 2004) from the Podhale Flysch are in contrast with the values of $0.40-0.82 \%$ in flysch from the OWC, as reported above. $R_{r}^{\circ}$ values from borehole samples in the Podhale Flysch reach the maximum values of $2.37-2.42 \%$ in the Zakopane IG 1, whereas, in the southernmost boreholes of Nowy Targ PIG 1 and Obidowa IG 1 in the OWC, the values are as low as $\sim 1.00 \%$

The Podhale Flysch basin was not subjected to fold-and-thrust tectonic movements, but did experience vertical tectonic movements related to the uplifting of the Tatra Massif, suggesting that coalification in the Podhale sediments was related to subsidence and burial linked to regional tectonics (Birkenmajer, 1988). Variations in coalification in the OWC also reflect subsidence and burial in an area that was also subjected to syn-orogenic tectonic uplift and thrusting. Poprawa et al. (2002) suggested that basin-floor topography was relevant there.

\section{CARPATHIAN OROGEN AND THE ALPS}

Not surprisingly, many similar explanations have been proposed to explain variations in random vitrinite reflectance in the
Alps and the Carpathians. Schuller (2004), dealing with the evolution of the Upper Cretaceous sedimentary basin in the Apuseni Mts. (Romania), concluded that depth profiles showing abrupt "jumps" in $R_{r}^{\circ}$ values were a consequence of post-sedimentary tectonic activity resulting in numerous stratigraphic unconformities. Schuller (2004) also noted instances of increased $R_{r}^{o}$ values in the upper parts of flysch profiles, caused by thrusting within the nappes. The lowering was not a consequence of stratigraphic inversion, but indicates that the main stage of coalification was completed before the final stage of thrusting and folding (Hufnagel et al., 1981; Jacob et al., 1982; Wagner et al., 1986). Furthermore, values of $R_{r}^{\circ}$ do not correlate with stratigraphic position within a given structural unit, indicating that coalification likely occurred during postdepositional events (Kuckelhorn and Hiltmann, 1992). Additionally, surface samples reveal a trend of increasing $R_{r}^{\circ}$ towards the south and south-east (Jacob et al., 1982; Wagner et al., 1986).

Soták et al. (2001) similarly argued that the changes in $R_{r}^{\circ}$ are not related to the depth and stratigraphy of the Paleogene section in the Central Carpathian Basin of northeastern Slovakia. Soták et al. (2001) explained the values of $R_{r}^{\circ}$ $(0.70 \%)$ characterizing both the Upper Oligocene formations and Lower Oligocene deposits at a depth of $2000 \mathrm{~m}$ as due to Late Oligocene subsidence related to the accumulation of molasse in an intermountain basin and to load-driven bending of the basement. The bending possibly led to higher heat flow in the Upper Oligocene deposits.

In the eastern part of the Slovakian basin, Soták et al. (1995) obtained high thermal maturity of organic matter in Eocene sediments. Vitrinite reflectance values $\left(R_{\min } 3.37 \%\right.$, $R_{\max } 5.57 \%$ ) show a sub-greenshist metamorphism grade as a result of hinterland extension related to intra-plate accretion.

Belkin et al. (2010), in discussing $R_{r}^{o}$ variations in Oligocene bituminous coal in the Petroşani Basin (Romania), concluded that high-rank coal was due to the migration of hydrothermal fluids. $R_{r}^{\circ}$ values, increasing from NE to SW there, accord with the direction of thrusting and trend perpendicular to major strike-slip faults (Sperner et al., 2002). Strike-slip faults are typical for the Inner and Southern Carpathians, distinguishing them from the Outer and Eastern Carpathians where thrusts prevail (e.g., Marko et al., 1991; Nemčok, 1993; Kovăč et al., 1994; Fodor, 1995; Decker and Perreson, 1996). Regional changes in $R_{r}^{\circ}$, controlled by burial related to extension and to intrusive volcanism in the Southern Alps, were emphasized by Zattin et al. (2006). Peaks of maximum temperature and maximum subsidence do not overlap, but are related to the occurrence of successive volcanic intrusions. Mählmann (2001) described thrust-related "jumps" in $R_{r}^{\circ}$ values in depth profiles of nappes in the central part of the Alps (Switzerland) and noted that elevated $R_{r}^{\circ}$ values are associated with migration of hydrothermal fluids $\left(270^{\circ} \mathrm{C}\right)$ along faults and thrusts. Mählmann (1995, 1996) had earlier emphasised the significant role of heating and its duration on coalification in the Alps of eastern Switzerland.

Reinhardt (1991) described the variability of $R_{r}^{\circ}$ values in nappes of the eastern Apennines. He interpreted signs of graphitisation in areas with the greatest estimated temperatures $\left(\sim 300^{\circ} \mathrm{C} ; \mathrm{R}_{\max } 4-7 \%\right)$ as due to the fact that large rock units were first buried to a depth of $\sim 5 \mathrm{~km}$ before being rapidly thrust over large distances. In the southern Alps of Austria, Rantitsch $(1992,1997)$ used $R_{r}^{\circ}$ values $(2.0-2.8 \%$; semi-anthracite) to show that clastic rocks had been subjected to hydrothermal activity $\left(350-400^{\circ} \mathrm{C}\right)$ related to plutonic activity in an Oligocene fault zone, the Peri-Adriatic Lineament. In addition, $R_{r}^{\circ}$ values increase from south to north, i.e. from footwall to hanging wall. In the Peri-Adriatic Lineament, Sachsenhofer (1992, 2001) attributed $R_{r}^{\circ}$ anomalies in coal-bearing forma- 
tions to volcanic activity; $R_{r}^{\circ}$ values in the vicinity of volcanic centres range from $1.00-1.30 \%$, whereas, in rocks several kilometres distant, the values are $<0.40 \%$. Dunkl et al. (1998) disputed Rantitsch's and Sachsenhofer's findings, arguing that not all the anomalies are volcanic-related. Syn-rift formations in the hanging wall of the fault zone show $R_{r}^{\circ}$ values of $0.67-1.04 \%$, which they attribute to burial of the hanging wall to a depth of $\sim 1500 \mathrm{~m}$ during the final rifting phase of the Pannonian Basin (Tari and Horváth, 1995).

Indications of Miocene volcanism related to the folding of nappes have been noted in the Paleogene of the Magura Nappe and Pieniny Klippen Belt in the Western Flysch Carpathians (Birkenmajer, 1979). This opens the possibility that heating and hydrothermal activity related to Miocene volcanism effected coalification in the Magura Flysch. Though the present research included samples from regions of andesite occurrence, i.e. Maniowy (0.82\%) and Krościenko nad Dunajcem (0.60-0.71\%), none were collected from, e.g. contact zones of dikes with flysch. Though the trend of southward-increasing $R_{r}^{\circ}$ in the Magura Nappe might suggest a link with Miocene volcanism, increases in $R_{r}^{\circ}(1.00-1.30 \%)$ as reported by Rantitsch $(1992,1997)$ and Sachsenhofer (1992) are not seen. In the southern part of the Outer Carpathians, coalification of organic matter could not be attributed to volcanism. The obvious $R_{r}^{\circ}$ anomalies in the Silesian Unit are also clearly unrelated to volcanism.

\section{CONCLUSIONS}

In the OWC, degrees of vitrinite coalification in surface rocks reveal no relationship with ages of lithostratigraphic formations due to their regional distribution (occurrences). Organic matter in the Oligocene rocks of lower units in tectonic windows, e.g. Magura Unit, can show higher degrees of coalification than similar organic matter in older formations of upper units. Furthermore, samples both from the Cretaceous (Lanckorona MS 183; Szczyrk MS 131) and Paleogene formations (Kamesznica MS 178; Zegartowice MS 47; Znamirowice MS 53) may all define areas of higher degrees of coalification $\left(R_{r}^{\circ}=0.63 \%-0.73 \%\right)$ in the Silesian Unit, despite the age difference. In a regional approach, variations in the degree of coalification shown by surface samples provide problematical results, as large horizontal thrusts, tectonic slicing within nappes, and erosion disrupt the stratigraphic continuity of the flysch formations. The recognition of clear trends is inhibited, however, in the southern part of the Magura Unit; an increase in organic matter rank is evident. The increasing degree of coalification in the southern part of the Magura Unit is not influenced by the stratigraphic position, but may be attributed to flexural bending of the basement due to subduction and deeper subsidence related to accretionary prism pressure. Isolines of $R_{r}^{\circ}$ illustrate the pattern of the main fold structures. In the western part of the Outer Carpathians, the Magura Nappe is characterized by numerous SW-NE synclines and anticlines. $R_{r}^{\circ}$ values follow a similar course. Further east in the nappe, a block-faulted structure prevails.

The relationship of increasing $R_{r}^{\circ}$ with depth is observed in boreholes. There is a correlation between the coalification degree and the age of flysch formations; the older the formation, the higher the value of $R_{r}^{\circ}$. In the Nowy Targ PIG 1, Poręba Wielka IG 1, Głogoczów IG 1 and the lower section of Obidowa IG 1 boreholes, tectonically undisturbed intervals show an ageand depth-related increase in $R_{r}^{\circ}$ values. In other boreholes, the variation in $R_{r}^{\circ}$ with depth ("jumps") is underlined by overthrusts between nappes.

The beginning of coalification was pre- and syn-orogenic and the final stages preceded the main folding and thrusting because:

1. The degree of organic matter coalification in the boreholes depends on the depth and stratigraphic position. Variability in $R_{r}^{\circ}$ determines thrust and fold surfaces among the structural units;

2. In the Magura Unit, areas with the highest $R_{r}^{\circ}$ values match areas of the highest subduction-related subsidence. Thermal maturity of organic matter occurred at time of accretion of the Magura wedge;

3. Anomalous degrees of coalification, deviating from the S-SE trend in the structural units, reflect the topography of the sub-basin floor.

Acknowledgements. This study was supported by Statutory Funds of AGH University no. 11.11.140.562. The author is grateful to Prof. J. Soták, Dr. P. Wójcik-Tabol and an anonymous reviewer for their helpful remarks. The author is also indebted to P.S. Kennan, University College Dublin, for improving the English text. Special thanks are to Prof. T. Peryt for his editorial work.

\section{REFERENCES}

Belkin, E.H., Tewalt, S., Hower, J.C., Stucker, J.D., O'Keefe, J.M., Tatu Calin, A., Buia, G., 2010. Petrography and geochemistry of Oligocene bituminous coal from the Jiu Valley, Petrosani basin (southern Carpathian Mountains), Romania. International Journal of Coal Geology, 82: 68-80.

Besserau, G., Roure, E., Kotarba, A., Kuśmierek, J., Strzetelski, W., 1997. Structure and hydrocarbon habitat of the Polish Carpathians. Mémoires du Muséum National d'Histoire Naturelle, Paris, 170: 343-373.

Birkenmajer, K., 1979. Przewodnik geologiczny po pienińskim pasie skałkowym (in Polish). Wyd. Geol., Warszawa.

Birkenmajer, K., 1986. Stages of structural evolution of the Pieniny Klippen Belt, Carpathians. Studia Geologica Polonica, 88: 7-32.
Birkenmajer, K., 1988. Exotic Andrusov Ridge: its role in plate-tectonic evolution of the units of the Magura Nappe, Krynica Subunit, Carpathians. Annales Societatis Geologorum Poloniae, 59: 145-181.

Borys, Z., Cisek, B., Czernicki, J., 1989. Nowe perspektywy poszukiwań złóż węglowodorów w piaskowcach dolnej kredy jednostki skolskiej w Karpatach (in Polish). Nafta, 10-12: 142-147.

Buła, Z., Habryn, R., Jachowicz-Zdanowska, M., Żaba, J., 2015 The Precambrian and Lower Paleozoic of the Brunovistulicum (eastern part of the Upper Silesian Block, Southern Poland) the state of the art. Geological Quarterly, 59 (1): 123-134.

Burtan, J., Cieszkowski, M., Mastella, L., Paul, Z., 1992. Okno tektoniczne Mszany Dolnej (in Polish) In: Przewodnik LXIII Zjazdu PTG, Koninki, 17-19 września 1992: 76-80. 
Cieszkowski, M., Golonka, J., Krobicki, M., Ślączka, A Waśkowska-Oliwa, A., Wendorff, M., 2009. Olistolites in the Silesian unit and their relationship with the phases of development of the Silesian basin (in Polish with English summary). Kwartalnik AGH Geologia, 35: 13-21.

Curtis, J.B., Kotarba, M.J., Lewan, M.D., Więcław, D., 2004 Oil/source rock correlation in the Polish Flysch Carpathian and Mesozoic basement and organic facies of the Oligocene Menilite Shales: insights from hydrous pyrolysis experiments. Organic Geochemistry, 35: 1573-1596.

Decker, H., Perreson, H., 1996. Tertiary kinematics in the Alpine-Carpathian-Pannonian system: links between thrusting, transform fautling and crustal extension. EAGE Special Publications, Geological Society, 5: 17-21.

Dunkl, I., Grasemann, B., Frisch, W. 1998. Thermal effects of exhumation of a metamorphic core complex on hanging wal syn-rift sediments - an example from the Rechnitz Window, Eastern Alps. Tectonophysics, 297: 31-50.

Fodor, L., 1995. From transpression to transtension: Oligocene-Miocene structural evolution of the Vienna basin and the East-Alpine-Western Carpathian junction. Tectonophysics, 242: 151-182.

Golonka, J., 2007. Tektonika polskich Karpat fliszowych pomiedzy Bielskiem-Białą a Nowym Targiem (in Polish). Kwartalnik AGH Geologia, 33: 29-38.

Golonka, J., Krobicki, M., Matyszkiewicz, J., Olszewska, B., Ślączka, A., Słomka, T., 2005. Geodynamice of ridges and development of carbonate platforms within the Outer Carpathian realm in Poland. Slovak Geological Magazine, 11: 5-16.

Hempel, I., 1955. Bedrock oil Carpathians (in Polish with English summary). Przegląd Geologiczny, 3: 468-473.

Hufnagel, H., Kuckelkorn, K., Wehner, H., Hildebrand, G., 1981 Interpretation des Bohrprofils Vorderriss 1 aufgrund organogeochemischer und geophysikalischer Untersuchungen. Geologica Bavarica, 81: 123-143.

International Committee for Coal and Organic Petrology (ICCP), 1998. The new vitrinite classification (ICCP System 1994): Fuel, 77: 349-358.

Jacob, H., Kuckelkorn, M., Müller, M., 1982. Inkohlung und Tektonik im Bereich der gefalteten Molasse. Erdöl Kohle, 35 510-518.

Jugowiec-Nazarkiewicz, M., Jankowski, L., 2001. Nannoplankton biostratigraphy of the Żegocina marls: an aspect of geologic setting of the Lanckorona-Żegocina Zone (in Polish with English summary). Przegląd Geologiczny, 49: 1186-1190.

Kępinska, B., 2006. Thermal and hydrothermal conditions of the Podhale geothermal system. Studia, Rozprawy, Monografie IGSMiE PAN w Krakowie, 135: 1-112.

Konon, A., 2001. Tectonics of the Beskid Wyspowy mountains (Outer Carpathians, Poland). Geological Quarterly, 45 (2) 179-204.

Kosakowski, P., 2013. 1D modelling of hydrocarbon generation and expulsion from Oligocene Menilite source rocks in the San and Stryi rivers region (Polish and Ukrainian Carpathians). Geological Quarterly, 57 (2): 307-324.

Kosakowski, P., Więcław, D., Kotarba, M., 2009. Source rock characteristic of the selected flysch deposits in the transfrontier area of the Polish Outer Carpathians. Kwartalnik AGH Geologia, 35: 155-190.

Kotarba, M., Nagao, K., 2008. Composition and origin of natura gases accumulated in the Polish and Ukrainian parts of the Carpathian region: gaseous hydrocarbons, noble, gases, carbon dioxide and nitrogen. Chemical Geology, 255: 426-438.

Kotarba, M.J., Więcłąw, D., Koltun, YV., Marynowski, L., Kuśmierek, J., Dudok, I.V., 2007. Organic geochemical study and genetic correlation of natural gas, oil and Menilite source rocks in the area between San and Stryi rivers (Polish and Ukrainian Carpathians). Organic Geochemistry, 38: 1431-1456.

Kovač, M., Kral, J., Marton, M., Plasienka, D., Uher, P., 1994. Alpine uplift history of the Central Western Carpathians: geochronological, paleomagnetic, sedimentary and structural data. Geologica Carpathica, 45: 83-96.
Kruge, M.A., Mastalerz, M., Solecki, A., Stankiewicz, B.A., 1996. Organic geochemistry and petrology of oil source rocks, Carpathian overthrust region, southeastern Poland - implication for petroleum generation. Organic Geochemistry, 24: 897-912.

Książkiewicz, M., 1972. Budowa geologiczna Polski (in Polish). Tektonika. Wyd. Geol., Warszawa.

Książkiewicz, M., 1977. Tectonics of the Carpathians. In: Geology of Poland (ed. W. Pożaryski), Tectonics, 4: 476-604. Wyd. Geol., Warszawa.

Kuckelkorn, K.F., Hiltmann, W., 1992. New maturity interpretation of Alpine overthrusting, Bavaria, Germany. EAPG Special Publication, 2: 177-184

Kuśmierek, J., 1990. Geodynamics outline of the Centra Carpathian Petroleum basin (in Polish with English summary). Prace Geologiczne, 135: 1-69

Kuśmierek, J., 1995. Evolution and hydrocarbon potential of Polish Carpathians (in Polish with English summary). Prace Geologiczne, 138: 1-92.

Kuśmierek, J., 2004. Petroleum systems: primary hydrocarbon potential and prospective resources of oil and natural gas (in Polish with English summary). Gospodarka Surowcami Mineralnymi, 20: 27-53.

Lewan, M.D., Kotarba, M.J., Curtis, J.B., Więcław, D., Kosakowski, P., 2006. Oil-generation kinetics for organic facies Type II and IIS kerogen in the Menilite Shales of the Polish Carpathians. Geochimica et Cosmochimica Acta, $\mathbf{7 0}$ 3351-3368.

MähImann, R.F., 1995. The pattern of diagenesis and metamorphism by vitrinite reflectance and illite crystallinity in Mittelbunden and in the Oberhalbstein. Part 1. The relationship to stockwork tectonics. Schweizerische Mineralogische und Petrographishe Mitteilungen, 75: 85-122.

MähImann, R.F., 1996. The pattern of diagenesis and metamorphism by vitrinite reflectance and illite crystallinity in Mittelbunden and in the Oberhalbstein. Part 2. Correlation of coal petrographical and of mineralogical parameters. Schweizerische Mineralogische und Petrographishe Mitteilungen, 76: 23-46.

MähImann, R.F., 2001. Correlation of very low grade data to calibrate a thermal maturity model in a nappe tectonic setting, a case study from the Alps. Tectonophysics, 334: 1-33.

Marko, F., Fodor, L., Kováč, M., 1991. Miocene strike-slip faulting and block roration in Brezovskè Karpaty Mts. (Western Carpathians). Mineralia Slovaca, 23: 189-200.

Marynowski, L., Gawęda, A., 2005. Correlation between biomarkers and thermal maturity of the organic matter from the Paleogene sedimentary rocks of the Podhale Trough. Mineralogical Society of Poland, Special Papers, 25: 329-332.

Matyasik, I., 1994. Geochemistry of Menilite and Inoceramian Beds in Skole Unit. Nafta-Gaz, 6: 234-244.

Nemčok, M., 1993. Transition from convergence to escape: field evidence from the West Carpathians. Tectonophysics, 217: 117-142.

Nemčok, M., Nemčok, J., Wojtaszek, M., Ludhova, L., Klecker, R.A., Sercombe, W.J., Cieszkowski, M., Paul, Z., Coward, M.P., Ślączka, A., 2001. Reconstruction of Cretaceous rifts incorporated in the Outer West Carpathian wedge by balancing. Marine and Petroleum Geology, 18: 39-64.

Newman, J., Newman, N.A., 1982. Reflectance anomalies in Pike River coals: evidence of variability in vitrinite type with implication for maturation studies and "Suggate rank". New Zeland Journal Geology and Geophysics, 25: 31-45.

Oszczypko, N., 1992. Magura basin development in the Upper Cretaceous and Paleogene (in Polish with English summary). Przegląd Geologiczny, 40: 397-404

Oszczypko, N., 2004. The structural position and tectonosedimentary evolution of the Polish Outer Carpathians. Przegląd Geologiczny, 52: 780-791.

Oszczypko, N., 2006. Late Jurassic-Miocene evolution of the Outer Carpathian fold-and-thrust belt and its foredeep basin (Western Carpathians, Poland). Geological Quarterly, 50 (1): 169-194. 
Oszczypko, N., Ślączka, A., 1985. An attempt to palinspastic reconstruction of Neogene basins in the Carpathian foredeep. Annales Societatis Geologorum Poloniae, 55: 55-75.

Paul, Z., Ryłko, W.,Tomaś, A., 1996. The influence of consolidated basement on flysch distribution in the Polish Western Carpathians (in Polish with English summary). Przegląd Geologiczny, 44: 489-494.

Peszat, C., 1997. Petrographic texture and physical properties of thick-bedded Cergowa sandstones (Fx, Ta) in Grybów unit in Klęczany near Nowy Sącz (in Polish with English summary). Gospodarka Surowcami Mineralnymi, 15: 137-163.

Poprawa, P., Malata, T., Oszczypko, N., 2002. Tectonic evolution of sedimentary basins of the Polish part of the Outer Carpathians based on the subsidence analysis (in Polish with English summary). Przegląd Geologiczny, 50: 1092-1108.

Poprawa, P., Malata, T., Pécskay, Z., Banaś, M., Skulich, J., Paszkowski, M., Kusiak, M., 2004. Geochronology of crystalline basement ofthe western Outer Carpathians' sediment source areas - preliminary data. Prace Specjalne Polskiego Towarzystwa Mineralogicznego, 24: 329-332.

Rantitsch, G., 1992. Reflexionsmessungen an Graptolithen im Silur und Unterdevon der Karnischen Alpen. Jahrbuch der Geologischen Bundesanstalt, 135: 299-316.

Rantitsch, G., 1997. Thermal history of the Carnic Alps (Southern Alps, Austria) and its paleogeographic implications. Tectonophysics, 272: 213-232.

Reinhardt, M., 1991. Vitrinite reflectance, illite crystalinity and tectonics: results from the Northern Appenines (Italy). Organic Geochemistry, 17: 175-184.

Sachsenhofer, R.F., 1992. Coalification and thermal histories of Tertiary basins in relation to late Alpidic evolution of the Eastern Alps. Geologische Rundschau, 81: 291-308.

Sachsenhofer, R.F., 2001. Syn- and postcollisional heat flow in the Tertiaty Eastern Alps. International Journal of Earth Sciences, 90: 579-592.

Schuller, V., 2004. Evolution and geodynamic significance of the Upper Cretaceous Gosau basin in the Apuseni Mountains (Romania). Tübinger Geowissenschaftliche Arbeiten, A 70: 1-122.

Semyrka, G., 2009. Vitrinite reflectance and kerogen types in Eastern Carpathians boreholes (in Polish with English summary). Kwartalnik AGH Geologia, 35: 49-59.

Sikora, W., Borysławski, A., Cieszkowski, M., Gucik, S., Jasionowicz, J., 1980. Przekrój geologiczny Kraków-Zakopane (in Polish). Wyd. Geol., Warszawa.

Soták, J., Biroň A., Kotulová, J., Rudinec, R., Spišak, J., 1995. Geological structure of the East Slovak basin basement in the light of facts and regional tectonic context. Mineralia Slovaca, 27: $1-8$.

Soták, J., Pereszlenyi, M., Marschalko, R., Milicka, J., Starek, D., 2001. Sedimentology and hydrocarbon habitat of the submarine-fan deposits of the Central Carpathian Paleogene basin (NE Slovakia). Marine and Petroleum Geology, 18: 87-114.

Sperner, B., Ratschbacher, L., Nemčok, M., 2002. Intreplay between subduction retreat and lateral extrusion: tectonic of the Western Carpathians. Tectonics, 21: 1-24.

Stach, E., Makowsky, M.T., Teichmuller, M., Taylor, G.H., Chandra, D., Teichmuller, R., 1982. Stach's Textbook of Coal Petrology: 77-98. Borntraeger, Berlin.

Ślączka, A., 1996. O tworzeniu się Karpat Zewnętrznych (in Polish). Sprawozdanie $z$ Posiedzenia Państwowej Akademii Umiejętności, 59: 79-80.

Środoń, J., 2008. Diagenetic history of the Podhale flysch basin. Geoturystyka, 2: 45-50.

Środoń, J., Kotarba, M., Biron, A., Such, P., Clauer, N., Wójtowicz, A., 2006. Diagenetic history of the Podhale-Orava basin and the underlying Tatra sedimentary structural units (Western Carpathians): evidence form XRD and K-Ar of illite-smectite. Clay Minerals, 41: 747-770.
Świerczewska, A., 2005. The interplay of thermal and structural histories of the Magura Nappe (Outer Carpathians) in Poland and Slovakia. Mineralogia Polonica, 36: 91-144.

Świerczewska, A., Tokarski, A.K., 1998. Deformations bands and the history of holding in the Magura Nappe Western Outer Carpathians, Poland. Tectonophysics, 297: 73-90.

Syrek, M., 2009. Degree of coalification dispersed organic matter in Magura Unit and tectonic windows (Outer Carpathians) (in Polish with English summary). Materiały konferencyjne IV Krakowskiej Konferencji Młodych Uczonych, 17-19 września 2009: 195-202. https://www.researchgate.net/publication/280315286 Stopien uweglenia rozproszonego materialu _organicznego_w_jednostce_magurskiej_i_strefie_okiennej_K arpaty_Zewnetrzne

Tari, G., Horvát, F., 1995. Overview of the Alpine evolution of the Pannonian basin. In: Hungary, Extensional Collapse of the Alpine Orogene and Hydrocarbon Prospects in the Basement and Basin Fill of the Western Pannonian Basin (eds. F. Horvath, G. Tari and C. Bokor): 7-19, AAPG International Conference and Exhibition, Nice, Guidebook to fieldtrip no. 6, Hungary.

Tokarski, A.K., 1980. Dynamics of outer Carpathian Tertiary orogenesis. Publications of Institue of Geography Polish Academy of Sciences, A8: 129-141.

Wagner, L., Kuckelkorn, K., Hiltmann, W., 1986. Neue Ergebnisse zur alpinen Gebirgsbildung Oberösterreichs aus der Bohrung Oberhofen 1- Stratigraphie, Fazies, Maturität und Tektonik. Erdöl, Erdgas, Kohle 102: 12-19.

Wagner, M., 1980. Coal-bearing sediments from the Magura Unit (in Polish with English summary). Annales Societatis Geologorum Poloniae, 50: 99-117.

Wagner, M., 1992. Petrological research of Carpathians coal occurrences as a source for hydrocarbons (in Polish with English summary). Gospodarka Surowcami Mineralnymi, 8: 803-817.

Wagner, M., 2010. Petrologic results of coal occurrences from the Podhale flysch sediments (in Polish with English summary). Przegląd Górniczy: 116-119.

Wagner, M., 2011. Petrologic studies and diagenetic history of coaly matter in the Podhale flysch sediments, Southern Poland. Annales Societatis Geologorum Poloniae, 81: 173-183.

Więcław, D., Kotarba, M., Kowalski, A., Koltun, Y., 2012. Origin and maturity of oils in the Ukrainian Carpathians and their Mesozoic basement. Geological Quarterly, 56 (1): 158-168.

Wójcik-Tabol, P., 2006. Organic carbon accumulation events in the mid-Createcous rocks of the Pieniny Klippen Belt (Polish Carpathians) - a petrological and geochemical approach. Geological Quarterly, 50 (4): 419-436.

Wójcik-Tabol, P., 2015. Depositional redox of the Grybów succession (Oligocene, Polish Carpathians) in the light of petrological and geochemical indices. Geological Quarterly, 59 (4): 603-614.

Zattin, M., Cuman, A., Fantoni, R., Martin, S., Scotti, P., Stefani, C., 2006. Cooling during burial: the thermal record in the sediments of the Dolomite region (Central Alps, Italy). Tectonophysics, 414: 191-202.

Żelaźniewicz, A., Aleksandrowski, P., Buła, Z., Karnkowski, P.H., Konon, A., Oszczypko, N., Ślączka, A., Żaba, J., Żytko, K., 2011. Regionalizacja tektoniczna Polski (in Polish). Komitet Nauk Geologicznych PAN, Wrocław.

Żytko, K., 1999. Correlation of the main structural units of the Western and Eastern Carpathians (in Polish with English summary). Prace Państwowego Instytutu Geologicznego, 168: 25-44.

Żytko, K., Malata, T., 2001. Palaeogeographic position of the Obidowa-Slopnice unit in the Outer Carpathian basin (SE Poland) (in Polish with English summary). Przegląd Geologiczny, 49: 425-430.

PN-ISO-11760:2007/DIS 11760 - Classification of Coals.

ISO 7404-5:2009 - Part 5 - Method of determining microscopically the reflectance of vitrinite. 